\title{
Factors Related to Visitors' Experience of Orientation and Disorientation at MTC Karebosi Makassar
}

\author{
Musdaria $^{\mathrm{a}, *}$, Ria Wikantari ${ }^{\mathrm{b}}$, Afifah Harisah ${ }^{\mathrm{c}}$ \\ aArchitecture Department, Engineering Faculty, Hasanuddin University. Email: riarch2804@ gmail.com \\ ${ }^{\mathrm{b}}$ Architecture Department, Engineering Faculty, Hasanuddin University. Email: rwikantaria@gmail.com \\ cArchitecture Department, Engineering Faculty, Hasanuddin University. Email: harisahhussein@ gmail.com
}

\begin{abstract}
Architecture involves the perception of the personal environment and the community in designing to be able to orient users. That perception became the basis for designers to design public buildings. The shopping center is one of the most visited public buildings and often orients and disorients its users. MTC Karebosi is one of the shopping centers in Makassar with the concept of providing primary, secondary, and electronic merchandise needs in one place. The need can be purchased wholesale and retail at affordable prices which makes it one of the alternatives for people to shop in Makassar. As a place to sell wholesale and retail merchandise, the retails laying arrangements are designed to the maximum possible to get a large number of retails in a limited area. As a result, the existing retail looks solid and similar to each other. Because of that, the situation between the corridors to the destination looks similar to each other. These conditions make visitors unable to mark the corridors that pass to the destination so that sometimes visitors experience disorientation. This research aims to determine factors related to the visitor's orientation and disorientation experience and uses survey methods. Data collection uses questionnaires as research instruments. The results revealed that factors related to orientation are spatial aspects, functional aspects, visual aspects, cognitive mapping, and behavior. Factors related to disorientation are spatial aspects, functional aspects, visual aspects, cognitive mapping, behavior, and internal individuals. However, there is one different factor that is the individual internal factor in the disorientation experience whereas orientation is not found. This is because internal factors such as fatigue make it easy for a person to forget and not concentrate so that they experience disorientation.
\end{abstract}

Keywords: Cognitive mapping; functional and spatial; orientation and disorientation; shopping mall; wayfinding

\section{Introduction}

The ability of architecture to orient itself and users in space and time has become one of the basic characteristics in the discipline of architecture [1]. Architectural knowledge is closely related to the perception of the designers since each architectural object is designed and used by the subject, i.e. the person [2]. Architecture involves the perception of the personal environment and the community in designing to be able to orient users in buildings. In design, the environmental perception of different groups becomes more important because the users perceived environment and quality are different from the perception of the designer [3]. Therefore, it is important for an architect to understand the environmental perception of society when designing. This is intended so that the results of the building design can be easily understood by the user when looking for the destination of the disorientation experience can be minimized.

Disorientation involves a failed orientation [4]. The inability of architecture to orient itself makes the perceived environment unable to be perceived properly

*Corresponding author. Tel: +6285 299213407

Jalan Todoppuli No. 10,

Makassar, Sulawesi Selatan by the user. As a result, the user is unable to orient himself in the space so confusion finds its way and towards its destination. Most subjects rely primarily on architectural elements to find their way and purpose, whereas some subjects seem to rely primarily on sign and message [5].

The shopping center is one of the most visited public buildings and often orients and disorients its users. MTC Karebosi is one of the shopping centers in Makassar with the concept of providing primary, secondary, and electronic merchandise needs in one place. The need can be purchased wholesale and retail at a reasonably priced price that makes it one of the alternatives for people to shop in Makassar. As a place to sell wholesale and retail merchandise, the layout is designed to the maximum possible to get a large number of retails in a limited area. As a result, the existing retail look congested, and the situation between corridors with each other heading to the destination looks similar to each other.

The condition makes visitors disoriented when searching for destinations. In addition to the factors mentioned, there are other factors related to the visitor's orientation and disorientation experience. The problem is the issue in this article is why visitors experience orientation and disorientation when searching for 
destinations in MTC Karebosi. The issue is expected to determine the factors related to the orientation and disorientation experience of MTC Karebosi visitors.

\section{Literature Review}

\subsection{Orientation}

In the Oxford dictionary [6], orientation is defined as the type of purpose or interest a person or organization has; the act of directing your goals in the direction of a particular thing; a person's basic beliefs or feelings about a particular subject; training or information you provide before starting a new job or course, etc; the direction in which the object is facing. Orientation is a review to determine the right and correct attitude (direction, place, etc.); the underlying view of the mind, attention, or inclination [7].

Schulz [8] states that orientation is a function that allows humans to become homo viators that are part of their nature. Lynch [9] also states that orientation can be an inarticulable memory of a more structured navigational action or mental map or a series of sequences remembered. Orientation is the concept of human consciousness that guides decision-making and action (Kamper in Kling and Kruger [10]).

Based on the understanding, orientation can be interpreted according to context. If it relates to humans then it can be interpreted as a position search by drafting a concept of memory or a structured mental map or a series of sequences that are remembered to make decisions and actions. If it relates to a building according to the context of the architecture then it can be interpreted as the direction in which the object is facing or the object's tendency towards something.

\subsection{Spatial orientation}

Spatial orientation refers to a process by which a person knows where he or she is towards something [11]. Ohta [12] explained that spatial orientation is considered one of a series of processes that mediate an individual's contact with the physical environment and the implementation of responses in the environment. So spatial orientation is a process that mediates an individual with a static space or environment to know where it is.

Lynch [13] explained that the ability to be able to read signs or symbols is supported by the quality of the environment that has properties:

a. Legibility is the ease to be read or recognized and clarity of information. [13].

b. Imageability is a physical quality that relates to the attributes of identity and structure in mental imagery where that physical quality evokes a strong image in a particular observer. [13].

There are five space-oriented elements. These five elements reinforce the legibility and imageability of an environment when positioning themselves [13], i.e: path, edge, district, node, landmark. Passini in Tanuwidjaja [14] found a similarity to five architectural elements based on Lynch's theory [13] in the study of commercial buildings in Montreal. Passini in Tanuwidjaja [14] divided five architectural elements into oriented processes and found a way, i.e:

\section{a. Pathway}

Passini in Tanuwidjaja [14] divides two types of pathways, i.e; horizontal and vertical pathway. Horizontal pathways in the scale of buildings, i.e; corridors while vertical pathways are stairs, escalators, and elevators.

b. Edge

Edge in the scale of the building in the form of a barrier wall that is the outer wall of the building.

c. District

Districts in building scale can be large zones that have similar functions.

d. Node

Nodes in the scale of a building are circulation meetings or meeting areas that are used as gathering places.

e. Landmark

Landmarks in buildings can be empty rooms that have a function as a reference point to know a person's whereabouts, have special features, and the number is not much.

In addition to the architectural elements mentioned above, Passini in Tanuwidjaja [14] also revealed that signage systems are necessary to help orient and process wayfinding to destinations. Gibson [15] divided the signage system into four types, including:

a. Identification signs.

These signs display the name and function of a place or space.

b. Directional signs

These signs show the location of a place, an object, an event in the form of a name, symbol, image, and arrow direction.

c. Orientation signs

These signs offer the user an overview of its surroundings in the form of maps and clues.

d. Regulatory signs

These signs describe something a person may and should not do in a place or space.

\subsection{Architectural morphology}

Frankl in Ven [16] divided architectural morphology into four categories:

a. Spasial Aspects

This aspect relates to the development of architectural elements that integrate into one unit forming a space and vice versa, from one unit into a separate part.

b. Physical Aspects

This aspect relates to the development of forms that sustain the physical and mass form of the merging of architectural elements.

c. Visual Aspects

This aspect relates to the perception of the user looking at the shape of the architecture from one point of view or different points of view so that it can be viewed in its entirety.

d. Functional Aspects

This aspect relates to the development of architectural forms that govern the organization of space so that it can accommodate functional akivitas and user circulation. 


\subsection{Orientation functional}

The notion of orientation beforehand if the context is related to the building is the tendency towards something. If orientation and functional are combined, it means that the tendency of architectural forms in organizing space so as to accommodate functional activities and circulation of the user. According to Narrel [1], functional orientation is based on several things, i.e:

a. Fixed functional relationships

Architectural elements oriented in relationship to one another and create legibility of form and function [1]. From the clarity of these shapes and functions, architecture creates a fixed functional relationship of shapes and functions so that between elements can create a legible space for shapes and their functions to be able to orient.

b. Static and clear boundaries

Static boundaries are fundamental to understanding of orientation in architecture [1]. Building users will feel more focused on exploring the space if the existing boundaries do not change.

c. Legible identities

Architectural identity is often rooted in materiality and qualities of the building materials that dominate the exterior and interior spaces. Architectural space forming materials affect the clarity of shapes and functions so as to orient the user of the building.

Orientation keeps users in touch with uninhabited places but is still part of the building [17]. Leatherbarrow [17] explains that functional orientation is based on:

a. Clear direction

Direction demands sense by determining and showing one's tendencies. Direction can also mean where the building gives the user directions to its destination.

b. Contrast differentiation

The differentiation of design elements makes destination destinations easier to do. Such is the wide difference for the main circulation in the retail and secondary circulation towards other facilities.

Coleman [18] identified a functional orientation based on his observations of various shopping malls he had seen based on:

a. Special differences

Specific differences can help identify a location or retail so it's easy to see.

b. Individual identity

Identity is required to remember and recognize the specific features a location or retail has when visitors want to come back.

c. Visual access to the outside of the building

To assist orientation such as mallswith long and complex circulation, there are points allowing views to the outside [18].

d. Same entry and exit points

Entry and exit points should be on the same way to assist the costumers's orientation and to allow them to retrace their route of arrival on departure [18].

e. Clarity of circulation

Clarity of circulation helps users to be able to explore the space easily so that users can linger and head to their destination in a shopping mall. f. Ease of access

Ease of access can help users to recognize entrances and exits so that users can enter and exit shopping malls without confusion.

\subsection{Wayfinding}

Wayfinding is a native function of environmental images that involves individual feelings where environmental images are a product of past experience memory and are used to interpret information and guide actions [13]. Wayfinding refers to the cognitive and behavioral abilities of humans and species to find a way from origin to destination [19]. Hunter et al [20] adapted Siegel and White's theory of environmental knowledge sequences in search of roads, namely landmark knowledge, route knowledge, and survey knowledge. route knowledge, and survey knowledge. Landmark knowledge is a search for information in the form of landmarks from the environment that are used as signs.

\subsection{Cognitive mapping}

Cognitive mapping is essentially everyday human life that is done when traveling then he will imagine: destinations, ways, routes, and locations he is known for [21]. When traveling a human takes and retails the information he obtains consciously or unconsciously. The process of encoding and decoding spatial knowledge is called cognitive mapping, defined as "a process consisting of a series of psychological transformations in which an individual acquires, codes, retails, remembers, and translates information about the relative location and attributes of phenomena in his or her daily spatial environment" (Downs and Stea in Hunter et al. [20]). Figure 1 shows the cognitive mapping formation scheme.

\subsection{Cognitive maps}

Cognitive maps are mental processes that contain a series of psychological transformations from information received, categorized, or coded, stored, conveyed in a description of a location of phenomena that mark spatial environments or spaces in daily life [21]. Cognitive map as a concept of cognitive mapping [3]. Cognitive maps in

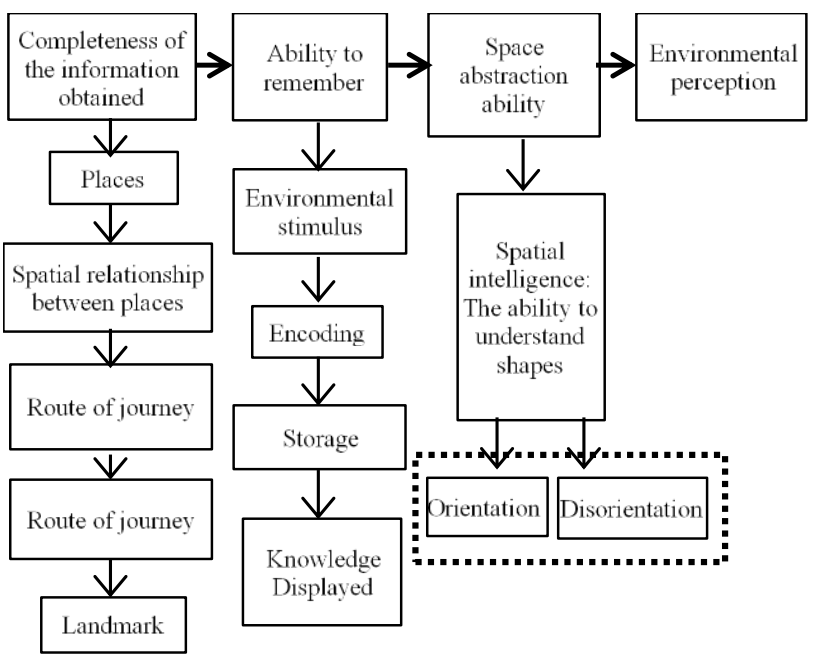

Figure 1. Factors in cognitive mapping [21] 
small and medium-sized environments are obtained primarily through direct experience on the go from place to place according to knowledge of the perception of the characteristics of a place [5].

\subsection{Perception}

Perception is a way of seeing things [4]. This understanding indicates that perception is based on the quality of the human senses to be able to see, hold, feel, and understand. Perception depends on orientation [3]. Without being oriented and located in space and time, organisms cannot see-make hypotheses, gather information from the environment and test this hypothesis (Bruner and Sandström in Rapoport [3]); also can't enjoy the environment.

Human perception involves images (Mann and Berry in Rapoport [3]). In the world of architecture, an image is an imitation or reproduction or a comparison of something [22]. The image of the environment possessed by observers depends on past experiences, current motivations and attitudes [22]. When a human enters a new building, such as a newly built mall, there is an image built based on his experience entering the mall before. If an image of an object is given meaning then the image will become a symbol for the next to be remembered. Symbols are the result of the cognition process; which means an object acquires a connotation (additional understanding) outside of its usefulness [22].

\subsection{Architectural perception}

Architectural perception is the sense of how something seen [3]. The basic perceptions that are in architectural design [2], i.e:

a. Functional perception

1) Space function: this approach emphasizes the way space is used in architectural design.

2) Space location: this approach emphasizes the situation of object location in architectural design.

3) Space form: this approach emphasizes the shape of objects in architectural design.

b. Persepsi visual

1) Space restrictions: this approach emphasizes the way space restrictions are designed.

2) Space order: emphasizes the connection of spaces in architectural design.

c. Structural perception

1) Space arrangement: this approach emphasizes the arrangement of objects with their environment in architectural design.

2) Spatial layout: this approach emphasizes the pattern of space in architectural design.

\subsection{Environmental perception}

Environmental perception is an interpretation of an individual's setting, based on the individual's cultural background, reasoning and experience [23]. Environmental perception is subjective, based on a person's personal view of the environment. Rapoport [3] associates environmental perception with the difference between emic and etic aspects. Emic is how something looks or is perceived by a person or group in a system. Etic is how observers perceive things in the same system.

\subsection{Perceived environment}

The perceived environment is a product or form of environmental perception of a person or group of people [23]. Perceived environments can be understood as ideas in people's minds based on what is known, expected, imagined, or experienced, and such ideas, which are often manifested in images and schemes [3].

\subsection{Disorientation}

Etymologically disorientation comes from the word dis- and orientation. According to the Great Dictionary of Indonesia [7] dis means bound form; no, not; separate and inverse or the opposite of. Orientation is a review to determine the right and correct attitude (direction, place, etc.); underlying views of thoughts, concerns or tendencies. So disorientation is a review of determining inappropriate and correct attitudes (direction, place, and so on).

\subsection{Spasial disorientation}

The terror of being lost comes from the necessity that a mobile organism be oriented in its surroundings [13]. To be oriented it takes a supportive orientation element to be able to determine the position of the building user. Spatial orientation elements according to Lynch [13] are path, edge, district, node, landmark. But if spatial disorientation occurs, then the user does not know the path, edge, district, node, landmark. Users also do not know and use signage.

\subsection{Functional disorientation}

Based on the determinants of orientation in architecture according to Narrel [1], Leatherbarrow [17], and Coleman [18] that functional orientation is based on some of the things mentioned above. Functional disorientation is based on:

a. Functional relationship are not fixed

b. Dynamic and unclear boundaries

c. Illegibility identities

d. Unclear directions

e. Noncontrast differentiation

f. Differences that are not specific

g. There is individual identity

h. There is visual access to the outside of the building

i. Entry and exit points are not the same

j. Unclearness circulation

k. Difficulty access

\section{Reasearch Method}

\subsection{Research type}

The type of research done is quantitative. This type of research is deductive, partial, and dualistis. It is deductive because the concept determination is done at the beginning so that it can be formulated hypothetically. It is partial because quantitative researchers consider that reality is singular and fragmental so that variables can be researched separately and separate unsentisive variables. 
Dualistis is the assumption that researchers' interactions with respondents are separate, make distances, and do not influence each other to produce objective research.

\subsection{Method}

This research method uses the survey method. In survey research, the analysis unit is an individual so one questionnaire is intended for one individual. In this case the individuals analyzed were visitors to MTC Karebosi.

\subsection{Research location}

As shown in Fig. 2, the research site is located in Indonesia, South Sulawesi province, Makassar city. Precisely located at MTC Karebosi on H. Oemar Said Cokroaminoto street, Nusakambangan street, and Ahmad Yani street. MTC Karebosi consists of nine floors namely two basement floors, six floors of shopping area and one floor for the manager. The shopping area consists of lower ground floor, ground floor, 1st floor, 2nd floor, 3rd floor, and 4th floor.

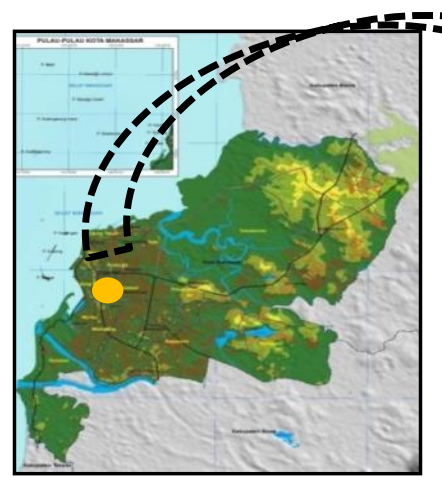

(a)

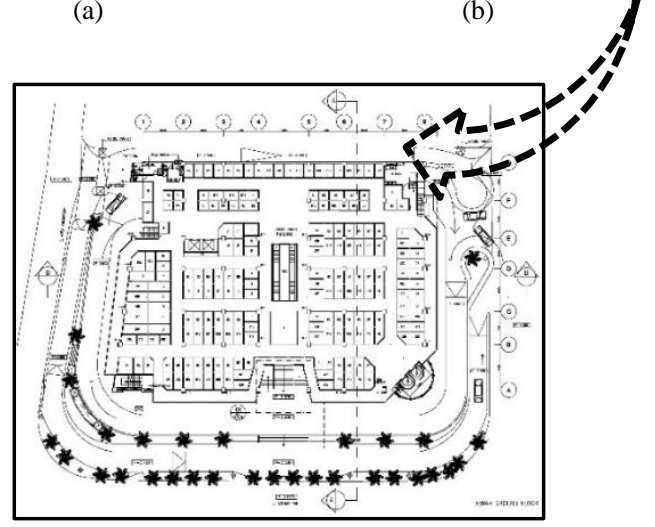

(c)

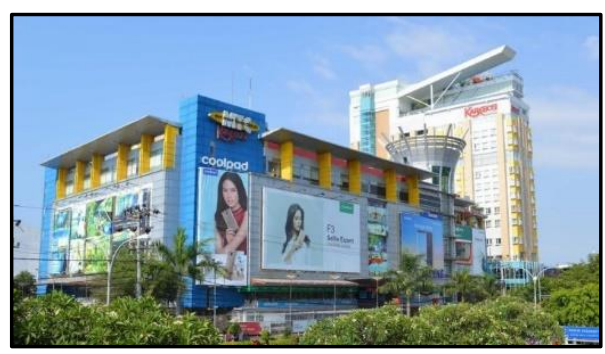

(d)

Figure 2. Location under study. (a) Makassar city map, (b) MTC Karebosi location map, (c) MTC Karebosi floor plan, (d) MTC facade

\subsection{Sample}

The number of MTC populations is unpredictable so to determine the number of samples, researchers did their way with expert formulations. The expert formulation is to determine the number of samples purposive-quota. Purposive sampling with criteria: being inside the MTC or having come to MTC in the past year. Sampling quota is set as much as 60. Existing statistical tests are very effective when applied to samples 30 to 60 (Champion in Indrawan [24]).

\subsection{Research data source}

a. Primary data

Primary data sources are based on observations, questionnaires, and interviews. Observations were carried out inside MTC karebosi by looking at the condition of exits, escalators, elevators, retails, and corridors. Questionnaires and interviews were conducted to 60 respondents who were in MTC and who had come to MTC in the past year.

b. Secondary data

Secondary data sources in the form of data supporting research from related agencies are MTC karebosi building plans, books related to the research, and the results of publications that support the research.

\subsection{Research instruments}

Research instruments are tools that researchers use in retrieving data. In this study, the research instruments are:

a. Questionnaire

The questionnaire that is shared is a closed and open questionnaire. The closed questionnaire consists of a list of questions consisting of two answers namely 'yes' and 'no'. The open questionnaire is that respondents are welcome to write down the reasons why answering 'yes' and why answer 'no'

b. Measurement scale

The measurement scale used in this study is guttman scale. This scale has only two answers in the questionnaire: 'yes' and 'no'. A value of 1 is given for the answer 'yes' and a value of 0 for the answer 'no'.

c. Voice recorder

Voice recorder is digital voice recorders are used to record the results of respondents' interviews.

\subsection{Research variables}

The research variable is a single variable. It consists of only one variable: factors related to the orientation and disorientation of visitors.

\subsection{Validity and reliability test}

a. Validity test

To test guttman scale validity, first sort questions from easy questions to difficult questions answered by respondents. Questions are sorted by calculating the score value of each question. The score calculation is based on the number of 'yes' answers given by all respondents in each question. The question that has the 
highest score is the easiest question and the lowestscoring question is the hardest question. After that each respondent's error value is calculated and the overall error value was entered into the formula:

$$
C R=1-(e / n \times k)
$$

where

$$
\begin{array}{ll}
C R & : \text { Coefficient of Reprodisiability } \\
e & : \text { error value } \\
n & : \text { number of value questions } \\
k & : \text { number of respondents }
\end{array}
$$

Next, the data is then calculated again using the Scalability Coefficient (CS) formula. The formula is:

$$
C S=1-(e / 0.5(n \times k))
$$

where

CS : Coefficient of Scalability

$e \quad$ : error value

$n \quad$ : number of value questions

$k \quad$ : number of respondents

The perfect coefficient value for CR is 0.9 and $\mathrm{CS}$ is 0.6 [25]. However, in practice to achieve a high coefficient of validity is relatively difficult. If the validity of obtaining a high value then the reliability value will drop. And vice versa. Therefore, coefficients ranging from 0.3 to 0.5 have been able to contribute well to the efficiency of a training institution (Cronbach in Azwar [26]).

\section{b. Reliability test}

For guttman scale, reliability test using KuderRichardson formula 21 (KR21), i.e:

$$
r_{i}=\frac{k}{k-1}\left(1-\frac{M(k-M)}{k\left(s t^{2}\right)}\right)
$$

where

$$
\begin{array}{ll}
r_{i} & : \text { reliability } \\
M & : \text { mean value } \\
s t^{2} & : \text { variance of total } \\
k & : \text { number of respondents }
\end{array}
$$

The reliability test limit is $>0.6$. If reliability has a coefficient $<0.6$ is not good, coefficient $0.7-0.8$ is acceptable, and $>0.8$ is good. However, sometimes a not-so-high coefficient can still be considered significant enough, seeing the size of the standard error in measurement is more important because the reliable test is the least variance error [26]. Variance error formula, i.e:

$$
s_{e}=s t \sqrt{1-r_{i}}
$$

where

$$
\begin{aligned}
& \text { : variance of error } \\
& \text { : variance of score } \\
& : \text { score of reliability }
\end{aligned}
$$

\subsection{Data analysis techniques}

Descriptive analysis is used to explain factors that affect the orientation and disorientation of MTC visitors. The presentation of data is a percentage table and describes them one by one.

\section{Validity and Reliability Test}

\subsection{Validity}

The number of variable error values of related factors (e) is 62 . The number of variable questions of related factors (n) amounts to 6 questions. The number of respondents $(\mathrm{k})$ is 60 . The value was included in the Coefficient of Reprodisiability (CR) formula.

$$
\begin{aligned}
C R & =1-(e / n \times k) \\
& =1-(62 / 6 \times 60) \\
& =1-0.172 \\
& =0.828 \\
& =0.83
\end{aligned}
$$

The CR value is $0.83<0.90$, so it is concluded that the variable question of related factors approaches the recommended Coefficient of Reprodisiability (CR) of 0.9 . A value of 0.83 is considered satisfactory. After calculating the CR value, the Coefficient of Scalability (CS) value was calculated based on the formula below:

$$
\begin{aligned}
C S & =1-(e / 0.5(n \times k)) \\
& =1-(62 / 0.5(6 \times 60)) \\
& =1-(62 / 180) \\
& =0.66
\end{aligned}
$$

The CS value is $0.66>0.60$ so that the variable question of related factors exceeds the recommended Coefficient of Scalability (CS) so that it is considered good.

\subsection{Reliability}

Reliability test using Kuder Richardson formula 21 (KR21). Before entering values into the formula KR 21 first variance totals and means are calculated based on the total score of each respondent. The number of variable $(\mathrm{k})$ questions is 6 . The mean value $(\mathrm{M})$ is 3,717 and the total variance (st2) is 1,636. The value is included in the kr21 formula, i.e:

$$
\begin{aligned}
r_{i} & =\frac{k}{k-1}\left(1-\frac{M(k-M)}{k\left(s t^{2}\right)}\right) \\
& =\frac{6}{6-1}\left(1-\frac{3.717(6-3.717)}{6(1.636)}\right) \\
& =1.2(1-0.864) \\
& =0.162 \\
& =0.2
\end{aligned}
$$


The reliability value is $0.2<0.6$. These results are considered less good. However, low scores are still considered significant because what determines reliabel questionnaires is the small variance of errors. Error variant values, i.e:

$$
\begin{aligned}
s_{e} & =s t \sqrt{1-r_{i}} \\
& =1.28 \sqrt{1-0.2} \\
& =1.28 \times 0.89 \\
& =1.132
\end{aligned}
$$

The variance error score is 1.132 which means that this value is reliabel.

\section{Discussion}

A total of 60 respondents were asked questions about orientation and disorientation when searching for escalators when entering, searching for escalators while circling, searching for retails, choosing suitable exits, searching for elevators when entering, and searching for elevators while circling. The destination is considered to be quite representative of the experience most often experienced while in MTC Karebosi when searching for a way. Here's the percentage of visitors who experience orientation and disorientation when searching for destinations depicted in graphic form.

Figure 3 shows that the tendency of visitors to experience orientation is searching for escalators when entering and searching for escalators while circling MTC. When visitors enter the shopping area, escalators tend to be easy for almost all visitors (93.3\%). When circling within MTC, escalators are also likely to be easy for almost all visitors $(95 \%)$.

When searching for a retail and choosing the appropriate exit, the percentage of visitors who experience orientation and disorientation is not too far off. Visitors searching for a retail in MTC were less than half the visitors $(56.7 \%)$. Disorientated visitors (confusion) searching for a retail were less than half the visitors $(43.3 \%)$. Meanwhile, visitors who never wrongly chose a suitable exit were less than half the visitors $(58.3 \%)$. Visitors who once wrongly chose a suitable exit were less than half the visitors $(41.7 \%)$.

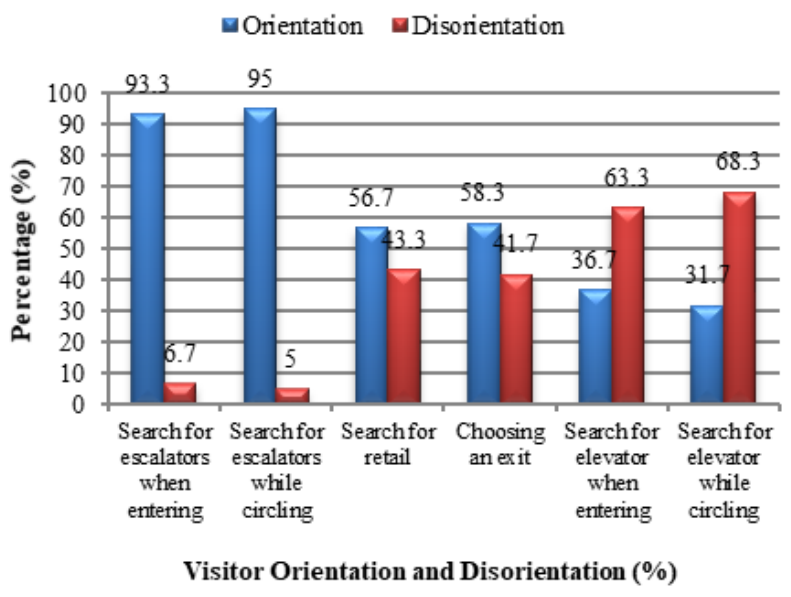

Figure 3. Percentage of visitors who experience orientation and disorientation when searching for destinations.
Furthermore, the percentage of visitors who experience orientation and disorientation when searching for an elevator is quite far. Visitors tend to experience disorientation when searching for elevators when entering or while circling. Visitors who experienced disorientation while searching for an elevator when entering were less than two-thirds of visitors $63.3 \%$ ). Visitors who experienced orientation while searching for elevators were less than a third of visitors $(36.7 \%)$. Meanwhile, visitors who experienced disorientation while searching for elevator while circling were less than two-thirds of visitors (68.3\%). Visitors who experience orientation when searching for elvators when circling are less than a third of visitors $(31.7 \%)$.

\subsection{Searching for escalator when entering}

The escalator is one of the transportation to the upper floors at MTC. Its strategic position makes it easy to find when entering. But there are still disorientations when looking for escalators. Here's why visitors experience orientation and disorientation when searching for escalators when entering Table 1.

a. Orientation

Based on the table above, the reason most visitors experience orientation is because the escalator is visible from the entrance $(55 \%)$. Then the second most reason is because of the continuous entrance and the escalator is visible $(16.7 \%)$. Furthermore, because the escalator is seen when go up the basement stairs (15\%). The escalator in the middle was the least reason put forward by respondents $(6.7 \%)$.

The reason visitors are dominated by escalators seen from several entry points illustrates that the position of the escalator is quite strategic. The escalator visible from several entry points is a landmark for MTC as it is visible from several visual points. Escalators as landmarks are part of the spatial orientation element needed for visitor orientation.

Meanwhile, the reason why the escalator is in the middle is the least answer expressed by respondents. MTC in the shape of a cube with the position of the escalator located in the middle of the building makes it easy for visitors to look for escalators upon entry. Its position in the middle is a product of the designer's structural perception of spatial arrangement. The perception makes it easy for visitors to look for escalators because it is in a strategic area that can be reached from various directions and often passed by visitors. This area is also a reference point for visitors to find the desired

Table 1. Reasons and percentage of visitors who experience orientation and disorientation when searching for escalators upon entry

\begin{tabular}{llll}
\hline $\begin{array}{l}\text { Orientation } \\
\text { Reasons }\end{array}$ & $(\boldsymbol{\%})$ & $\begin{array}{l}\text { Disorientation } \\
\text { Reasons }\end{array}$ & $(\boldsymbol{\%})$ \\
\hline $\begin{array}{l}\text { Visible from the entrance } \\
\begin{array}{l}\text { The escalator is in the } \\
\text { middle }\end{array}\end{array}$ & 55.0 & $\begin{array}{l}\text { Enter by elevator, so } \\
\text { the escalator is not } \\
\text { visible }\end{array}$ & 5.00 \\
$\begin{array}{l}\text { From the entrance just } \\
\text { keep going and the } \\
\text { escalator is visible }\end{array}$ & 16.7 & $\begin{array}{l}\text { Not visible from the } \\
\text { entrance }\end{array}$ & 1.7 \\
$\begin{array}{l}\text { Seen while go up the } \\
\text { basement stairs }\end{array}$ & 15.0 & Total & 6.7 \\
\hline Total & 93.3 & & \\
\hline
\end{tabular}


retail so that the escalator is a landmark in MTC Karebosi which is used as a marker.

\section{b. Disorientation}

Based on the table, it appears that visitors who enter use the elevator have difficulty finding escalators because they are not visible (5\%). In addition, visitors entering through the front door of Cokroaminoto street also have difficulty finding escalators because the escalator is not visible from the entry point $(1.7 \%)$. Although the percentage is quite small compared to visitors who experience orientation, this needs to be considered. Escalators and elevators are a means of transportation for visitors, so there needs to be visual access between the two facilities to facilitate visitors.

The reason visitors who have difficulty finding escalators when entering is because it is not visible from the elevator and not visible from the entrance shows that the visual access of visitors is blocked to the escalator. Visitors have difficulty accessing the escalator visually if entering using the elevator because of the elevator that is in the corner. Elevators and escalators are restricted by retails so visitors who enter using the elevator cannot see the presence of escalators. Visitors also have difficulty finding escalators from the entrance from the direction of Cokroaminoto and Nusakambangan streets as it is necessary to walk straight a few meters from the entrance to see the escalator. Rows of retails to pass through make the escalators invisible from the entrance.

\subsection{Searching escalators while circling}

Visitors who are circling and entering have different situations when searching for escalators. Therefore, the reasons expressed by visitors also vary. Here are the reasons and percentages of reasons visitors experienced orientation and disorientation in Table 2.

a. Orientation

Based on the table above, visitors are more oriented when looking for escalators while circling (95\%). The most common reason is that escalators are easy to find when walking around because they are in the middle $(75 \%)$. The second most reason is because there is ample and empty space around the escalator (6.7\%). Then visitors are easy to find escalators when circling because the escalator is visible from several points in the corridor and the corridor always leads to the escalator (5\%). The least common reason is that many visitors are seen in the area near the escalator and because the MTC is small (1.7\%).

The most reason that most respondents answered was easy to find escalators because the escalator was in the middle. The position of the escalator in the middle facilitates cognitive mapping of visitors due to its memorable location. The second most reason is because there is ample and empty space around the escalator so the escalator is easy to find. This reason clarifies the function of the area as a circulation area and a meeting point of circulation. This relates to the spatial element factor that is the path and node as the marker. Therefore, the importance of a marker around the escalator is different from other circulation lines so as to evoke the visitor's memory of the position of the escalator
Table 2. Reasons and percentage of visitors who experience orientation and disorientation when searching for escalators while circling

\begin{tabular}{|c|c|c|c|}
\hline \multirow{2}{*}{$\begin{array}{l}\text { Orientation } \\
\text { Reasons }\end{array}$} & \multirow[b]{2}{*}{$(\%)$} & \multicolumn{2}{|l|}{ Disorientation } \\
\hline & & Reasons & $(\%)$ \\
\hline Escalator in the middle & 75.0 & \multirow{2}{*}{$\begin{array}{l}\text { The escalator is not } \\
\text { visible because many } \\
\text { sellers are in the } \\
\text { middle of the building }\end{array}$} & \multirow[b]{2}{*}{1.7} \\
\hline $\begin{array}{l}\text { Many visitors are seen } \\
\text { in the area near the } \\
\text { escalator }\end{array}$ & 1.7 & & \\
\hline $\begin{array}{l}\text { Visible from several } \\
\text { points in the corridor }\end{array}$ & 5.0 & \multirow{2}{*}{$\begin{array}{l}\text { Invisible escalator } \\
\text { from the corner of the } \\
\text { building }\end{array}$} & \multirow[b]{2}{*}{1.7} \\
\hline $\begin{array}{l}\text { There is ample and } \\
\text { empty space around the } \\
\text { escalator }\end{array}$ & 6.7 & & \\
\hline $\begin{array}{l}\text { Corridors always lead } \\
\text { to escalators }\end{array}$ & 5.0 & \multirow{2}{*}{$\begin{array}{l}\text { Not all corridors lead } \\
\text { to escalators when } \\
\text { driving around }\end{array}$} & \multirow[t]{2}{*}{1.7} \\
\hline MTC has small size & 1.7 & & \\
\hline Total & 95.0 & Total & 5.0 \\
\hline
\end{tabular}

The escalator is visible from some point to be the next reason. This reasoning shows that due to its position in the middle makes the escalator visible from several points so it is easy to find when circling. In addition, the corridor also directly leads to the escalator being the next reason. Some corridors are created directly leading to the escalator so that when visitors stand at some point, then the escalator can be seen. The corridor leading to the escalator shows the importance of the path, part of the spatial element to get visitors directly to the destination. It makes visitors not confused looking.

The next reason is that visitors are easy to find escalators when circling because many visitors are seen in the area around the escalator, strengthening the function of the area around the escalator as a meeting circulation and selling place. Visitors who see many visitors gather are associated with seeing the behavior of others as a sign. The behavior strengthens the markers around spatial elements to be recognizable and remembered. Then the reason visitors are easy to find escalators when circling because the size of MTC is small is related to the ability to remember factor owned by each individual. This ability is part of the cognitive mapping process.

\section{b. Disorientation}

Visitors who experience disorientation when searching for escalators while circling no more than a twelfth of visitors (5\%). The reason visitors experience disorientation is that the escalator is invisible because many sellers in the middle of the building, the escalator is not visible from the corner of the building, and not all corridors are translucent to the escalator (1.7\%).

The reason for disorientation is contrary to visitors experiencing orientation. This difference in perception is due to the sometimes fickle MTC situation, especially the situation around escalators. The reason visitors say that escalators are invisible is because many sellers in the middle of the building are related to the absence of visual access of visitors. Large and empty space on escalators is sometimes filled by merchants who rent to sell. The reason for the invisible escalator from the corner of the building is also related to the absence of visual access to visitors. Visitors have difficulty visually accessing the escalator because the view is blocked by rows of retails. 
Furthermore, the reason that not all corridors are translucent to the escalator relates to spatial elements in the form of indirect paths pointing to the escalator. The grid-shaped circulation pattern makes the path form a branch so that when misselected the branching path, visitors will have difficulty finding escalators.

\subsection{Searching for retail}

The retail is the main facility in the shopping center. There are times when visitors want to visit a retail that has been visited before. Here's the percentage of visitors who experience orientation and disorientation when searching for a retail and why presented in Table 3 .

\section{a. Orientation}

Visitors who were oriented while searching for a retail were less than half the visitors $(55 \%)$. The most reason is to remember the position of the retail $(15 \%)$. The second most reason is to remember the position and name of the retail $(11.7 \%)$. The third most common reason is that the retail is often visited close to the escalator $(10 \%)$. The fourth most reason is to remember the position and seller of the retail $(8.3 \%)$. The fifth most reason is to remember the address of the retail block $(6.7 \%)$. Then the smallest percentage of the reason for visitors is to remember the position and logo of the retail, and remember the position and merchandise (1.7\%).

Visitors who experience orientation on the grounds of remembering the position of the retail, are closely related to the ability to remember which is part of cognitive mapping. Visitors who can remember the position of the retail, keep information related to the route that will be passed to the retail to be visited. So is the reason for remembering the retail because it remembers the position and name of the retail, remembers the position and seller of the retail, remembers the block address, remembers the position and logo of the retail, and remembers the position of the retail and the merchandise related to the

Table 3. The reason and percentage of visitors who experience orientation and disorientation when searching for retails that have been visited before

\begin{tabular}{|c|c|c|c|}
\hline Orientation & & Disorientation & \\
\hline Reason & $(\%)$ & Reason & $(\%)$ \\
\hline $\begin{array}{l}\text { Remember the block } \\
\text { address } \\
\text { Remember the } \\
\text { positions and name of } \\
\text { the retail }\end{array}$ & 11.7 & $\begin{array}{l}\text { The retails is similar in } \\
\text { size, sales, and wall } \\
\text { color }\end{array}$ & 15.0 \\
\hline $\begin{array}{l}\text { Remember retails } \\
\text { positions and logos }\end{array}$ & 1.7 & $\begin{array}{l}\text { Never come to the same } \\
\text { retails }\end{array}$ & 1.7 \\
\hline $\begin{array}{l}\text { Remember the } \\
\text { positions and seller of } \\
\text { the retail }\end{array}$ & 8.3 & $\begin{array}{l}\text { Corridors to branched } \\
\text { retail }\end{array}$ & 10.0 \\
\hline \multirow[t]{2}{*}{$\begin{array}{l}\text { Retails commonly } \\
\text { visited close to } \\
\text { escalators }\end{array}$} & \multirow[t]{2}{*}{10.0} & $\begin{array}{l}\text { The size of the retails } \\
\text { and the corridors that } \\
\text { pass through look the } \\
\text { same }\end{array}$ & 3.3 \\
\hline & & Retails too crowded & 6.7 \\
\hline $\begin{array}{l}\text { Remember the position } \\
\text { of the retails }\end{array}$ & 15.0 & $\begin{array}{l}\text { The retails is dense and } \\
\text { looks similar in size, } \\
\text { color, and sales }\end{array}$ & 6.7 \\
\hline $\begin{array}{l}\text { Remember positions } \\
\text { and merchandise }\end{array}$ & 1.7 & $\begin{array}{l}\text { Merchandise sold look } \\
\text { similar }\end{array}$ & 1.7 \\
\hline Total & 55.0 & Total & 45.0 \\
\hline
\end{tabular}

recall ability. But in this case the unique code by remembering the name, seller, logo, and merchandise is additional information in addition to the position of the retail.

Then the reason for remembering the retail is because the retail is commonly visited adjacent to the escalator, making the escalator as a marker or landmark to mark its position. The presence of landmarks is few in a building so landmarks become reference points that can orient the user. Therefore the placement of retails adjacent to landmarks is very helpful for users to know where they are.

\section{b. Disorientation}

Visitors who experience disorientation while searching for a retail are less than half the visitors (45\%). The most common reason is that the retails that are searched look similar to each other from the size, sales, and color of the walls (15\%). The second most reason is the corridor to branch retails $(10 \%)$. The third most common reason is that retails are too dense and retails are too dense and look similar to each other's size, sales, and wall color $(6.7 \%)$.

The fourth most common reason is that the size of the retails and the corridors that are passed when searching for a retails look the same $(3.3 \%)$. Then the least reason put forward by visitors is that the merchandise sold look similar $(1.7 \%)$. However, there is a reason that visitors never come to the same retail. This cannot be considered disoriented because it has never searched a retail that was visited before.

The reason visitors experience disorientation when searching for a retail because the retail looks similar from the size, sales, and color of the wall is a factor related to the absence of contrasting elements of the retail design with each other. The identity of a retail looks the same, there is no difference that contrasts with each other. This makes visitors unable to obtain information that can be used as a marker to remember the route. Then the reason about the size of the retails and the corridors that are passed looks the same and the merchandise sold look similar is also a functional disorientation factor that is a differentiation that does not contrast.

The reason visitors experience disorientation when searching for a retail is because the corridor to the branched retail describes the corridor line in MTC that forms the grid pattern. Corridor paths with grid patterns form branches at circulation meetings. The branching of the corridor shows that one of the spatial elements is that the path cannot direct visitors. Visitors are confused to choose the right path to find the retail to go to if the line is branched. Furthermore, the reason that the retail is too dense is the designer's functional perception. The functional perception of the designer that produces the design of the retail settings with such a small size gives a solid impression to the user. The retail seems crowded because of the small size of the retail and the squeaking of each other so that visitors can not look for the retail that has been visited. 
Table 4. The reason and percentage of visitors who experience orientation and disorientation when choosing the approriate exit

\begin{tabular}{|c|c|c|c|}
\hline Orientation & & Disorientation & \\
\hline Reason & $(\%)$ & Reason & $(\%)$ \\
\hline $\begin{array}{l}\text { Memorize the } \\
\text { corridors that } \\
\text { pass through }\end{array}$ & 15.0 & $\begin{array}{l}\text { Join the flow of other } \\
\text { visitors }\end{array}$ & 6.7 \\
\hline \multirow{2}{*}{$\begin{array}{l}\text { Same entry and } \\
\text { exit positions }\end{array}$} & \multirow[t]{2}{*}{11.7} & $\begin{array}{l}\text { The corridor leads to the } \\
\text { exit a lot, so it's wrong in }\end{array}$ & 1.7 \\
\hline & & Out of focus due to fatigue & 1.7 \\
\hline \multirow[b]{2}{*}{$\begin{array}{l}\text { Always pay } \\
\text { attention to the } \\
\text { signs }\end{array}$} & \multirow[b]{2}{*}{1.7} & $\begin{array}{l}\text { Wrong turn when } \\
\text { descending from escalator }\end{array}$ & 3.3 \\
\hline & & $\begin{array}{l}\text { The retail looks similar and } \\
\text { the merchandise is in the } \\
\text { corridor so the exit is not } \\
\text { visible }\end{array}$ & 3.3 \\
\hline \multirow{2}{*}{$\begin{array}{l}\text { Marking from the } \\
\text { escalators } \\
\text { position }\end{array}$} & \multirow{2}{*}{20.0} & $\begin{array}{l}\text { Can't remember which } \\
\text { floor }\end{array}$ & 8.3 \\
\hline & & $\begin{array}{l}\text { Elevator position is hard to } \\
\text { find }\end{array}$ & 1.7 \\
\hline \multirow{2}{*}{$\begin{array}{l}\text { Remember the } \\
\text { position in front } \\
\text { of the mobile } \\
\text { phone seller }\end{array}$} & \multirow[b]{2}{*}{1.7} & $\begin{array}{l}\text { Follow the escalator path } \\
\text { that continues to the lower } \\
\text { ground }\end{array}$ & 8.3 \\
\hline & & $\begin{array}{l}\text { Can't remember the } \\
\text { corridors being passed } \\
\text { through and no signage }\end{array}$ & 3.3 \\
\hline \multirow[b]{2}{*}{$\begin{array}{l}\text { The door looks } \\
\text { large from the } \\
\text { middle of the } \\
\text { building }\end{array}$} & \multirow[b]{2}{*}{8.3} & $\begin{array}{l}\text { The door is blocked by the } \\
\text { seller's desk }\end{array}$ & 1.7 \\
\hline & & $\begin{array}{l}\text { The atmosphere of the } \\
\text { corridors of each floor } \\
\text { looks the same from the } \\
\text { height of the ceiling, and } \\
\text { the arrangement of the } \\
\text { retail }\end{array}$ & 1.7 \\
\hline Total & 58.3 & Total & 41.7 \\
\hline
\end{tabular}

\subsection{Choose the appropriate exit}

MTC exits are available quite a lot so this sometimes makes visitors experience orientation and disorientation when choosing the desired exit. Table 4 shows why and percentage of visitors who experience orientation and disorientation when choosing the appropriate exit.

\section{a. Orientation}

Based on the table above, visitors who experienced orientation when choosing the exit as desired were fewer than half the visitors $(58.3 \%)$. The most reason visitors experience orientation is because it marks from the position of the escalator $(20 \%)$. Then the second most reason for memorizing the corridors passed $(15 \%)$. The third most reason for the same entrance and exit position $(11.7 \%)$. The fourth most reason is because the door looks large from the center of the building (8.3\%). Furthermore, the least reason from respondents is because always pay attention to the signs board and remember the position of the front exit of the mobile phone seller $(1.7 \%)$.

The reason visitors are that when choosing the appropriate exit by marking the position of the escalator, strengthens the function of the escalator as a landmark. Escalators as landmarks have a strong imageability so the marker is easy to recognize (legibility) and is used as a guide in oriented and finding a way. The reason that visitors can choose the appropriate exit is because memorizing the corridors that pass through is related to the ability to remember. The ability to remember is helped by finding information from around the world to become a marker. The information is stored and becomes knowledge then referenced when the next visit.

The reason for the same entrance and exit position makes it easy for visitors to choose the appropriate exit, showing that the similarity of position when entering and exiting affects the visitor's memory to be oriented. The same entrance and exit positions are part of the consideration in functional orientation. The reason that the door looks large from the center of the building, is related to the size of an object being used as a marker to orient and find a way. Furthermore, the reason for paying attention to signs and remembering the position of the front exit of the mobile phone seller, shows that the importance of a signage and other markers besides signage to be oriented and find a way. Considering the position of the front exit of the mobile phone seller is also part of the ability to remember from the cognitive mapping process.

\section{b. Disorientation}

Visitors who experienced disorientation when choosing the exit were less than half the visitors $(41.7 \%)$. The most reason visitors experience disorientation is because they do not remember which floor and follow the escalator path that continues to the lower floor (8.3\%). Then the second most reason for joining the flow of other visitors $(6.7 \%)$. The third most reason for the wrong turn when descending from the escalator, the retail looks similar and the merchandise is not neatly arranged so that the exit is not visible, and do not know which way to go and no directions $(3.3 \%)$. Furthermore, the reason with the smallest percentage is because the corridor to the exit is so wrong, the reach becomes out of focus, the elevator position is hard to find, the exit is blocked by the sales desk, and the atmosphere of the corridor of each floor looks the same from the size, height of the ceiling, and the arrangement of the retail $(1.7 \%)$.

The reason that visitors experience disorientation is because it does not remember which floor and follow the escalator path that continues to the lower floor, related to the lack of ability to remember the position of the exit so do not know the path that is passed to the exit. The second most reason for joining the flow of other visitors, shows the condition of visitors who follow the behavior of other visitors in the hope that the intended destination is in the same location. As a result, the intended exit is wrong because it follows the behavior of other visitors.

The third most reason is because of a wrong turn when descending from the escalator, can not remember the corridor that is passed and there are no signage, and the retail looks similar and the merchandise is in the corridor so the exit is invisible, related to the inability to remember, not knowing the signage, incontrasity of the design elements, and difficulty of visual access to the exit. The reason with the smallest percentage because the corridor to the exit is so much wrong to choose, out of focus due to fatigue, the position of the elevator is hard to find, the exit is blocked by the sales desk, and the atmosphere of the corridor of each floor looks the same from the size, height of the ceiling, and the arrangement of the retail, related to the path of incapable of directing, individual internal factors, invisible elevator position, 
difficulty visual access to the exit, and incontrasion of design elements.

\subsection{Searching for elevator when entering}

The elevator is a means of transportation provided for visitors to visit the desired floor in addition to the escalator. Table 5 explains why visitors and their percentage experience orientation and disorientation when searching for elevator when entering.

\section{a. Orientation}

Based on the table above, visitors experience orientation when searching for elevator when entering less than a third of visitors $(36.7 \%)$. The most reason visitors experience orientation when searching for an elevator when entering is because the elevator is visible from the basement $(11.7 \%)$. The second most reason is that there are signage to the elevator so that visitors are directed to the elevator $(10 \%)$. Then the third most reason is because of the memorization of the elevator position $(8.3 \%)$. The fourth most common reason is because the elevator is visible from the outside $(5 \%)$. The reason for having the smallest percentage is because many gather in front of the elevator $(1.7 \%)$.

The reason visitors experience orientation when searching for an elevator when entering is because the elevator is visible from the basement and visible from the outside, related to the ease of visual access. The position of the elevator in the corner of the building is easily visible from the basement because there is a lot of empty space so the visual visitors immediately see the basement in the corner of the building. The elevator is quite good at displaying its image as a vertical means of transport from the basement because the surrounding space that supports the elevator stands out. Then the reason that visitors know the entrance because there are signage to the elevator when entering, related to the signage position is known location so that visitors use it to the elevator. This shows the importance of a signage as an orientation element in finding a way.

The reason visitors know the position of the elevator when entering is because it memorizes the position of the elevator, related to the ability to remember which is part of cognitive mapping. The ability to remember due to the

Table 5. Reasons and percentage of visitors who experience orientation and disorientation when searching for elevators when entering

\begin{tabular}{|c|c|c|c|}
\hline \multirow{2}{*}{$\begin{array}{l}\text { Orientation } \\
\text { Reason }\end{array}$} & \multirow[b]{2}{*}{$(\%)$} & \multicolumn{2}{|l|}{ Disorientation } \\
\hline & & Reason & $(\%)$ \\
\hline \multirow{2}{*}{$\begin{array}{l}\text { Many gathered in front } \\
\text { of the elevator }\end{array}$} & \multirow{2}{*}{1.7} & $\begin{array}{l}\text { The position is in the } \\
\text { corner }\end{array}$ & 6.7 \\
\hline & & $\begin{array}{l}\text { The path is confusing } \\
\text { from the entrance }\end{array}$ & 6.7 \\
\hline $\begin{array}{l}\text { Elevator visible from } \\
\text { the outside }\end{array}$ & 5.0 & $\begin{array}{l}\text { Elevator not visible } \\
\text { from entrance }\end{array}$ & 38.3 \\
\hline There are signage & 10.0 & $\begin{array}{l}\text { There is no signage to } \\
\text { elevator }\end{array}$ & 5.0 \\
\hline \multirow{2}{*}{$\begin{array}{l}\text { Elevator visible from } \\
\text { basement }\end{array}$} & \multirow{2}{*}{11.7} & $\begin{array}{l}\text { Not visible from } \\
\text { basement stairs }\end{array}$ & 1.7 \\
\hline & & $\begin{array}{l}\text { Covered by } \\
\text { merchandise }\end{array}$ & 1.7 \\
\hline $\begin{array}{l}\text { Memorize elevator } \\
\text { position }\end{array}$ & 8.3 & Covered by retails & 3.3 \\
\hline Total & 36.7 & Total & 63.4 \\
\hline
\end{tabular}

information collected becomes a marker. This marker is then used as a reference so as to form a route to the destination. The next reason visitors experience orientation is because the elevator is visible from the outside, describing part of the situation of the MTC building's skin design that is transparent so that the elevator can be seen from the outside. The position of the elevator makes visitors can access it visually from the outside. Then the reason visitors experience orientation is because many gather in front of the elevator, showing the information obtained by visitors around MTC to find a way by seeing the behavior of others as a sign.

\section{b. Disorientation}

Visitors who experienced disorientation when searching for elevators while entering were less than a third of visitors $(63.3 \%)$. This percentage shows that most visitors find it difficult to find an elevator when entering. The most reason visitors experience disorientation when searching for an elevator when entering is because the elevator is not visible from the entrance $(38.3 \%)$. The second most reason is because of its position in the corner and the confusing path from the entrance $(6.7 \%)$. The third most reason is because there is no signage to the elevator $(5 \%)$. The fourth most reason is because elevators are covered by retails $(3.3 \%)$. Then the reason that has the smallest percentage amount is invisible from basement stairs and elevators covered by merchandise $(1.7 \%)$.

The reason visitors when searching for an elevator, not visible from the entrance, shows that the position of the elevator is not immediately visible to incoming visitors. The visual perception of the designer wants to expose the elevator by putting it in the corner to be visible from the outside. However, the position is not visible from the entrance so visitors are confused to find the elevator upon entry. Then, the reason visitors that the position of the elevator is in the corner and the path leading to the elevator is confusing from the entrance, describing the position of the elevator that is unknown because it is in the corner. Visitors are confused because they do not find a marker that provides information about which angle the elevator is in. Visitors are also confused because the path is not able to steer so the path is confusing. The reason visitors because there are no signage to the elevator is related to not knowing the signage so visitors do not use signage.

The reason visitors experience disorientation is because elevators are covered by retails, describing the laying of elevators that are not visually accessible. Furthermore, the reason visitors are oriented with the smallest percentage because the elevator is not visible from the basement stairs and the elevator is covered by merchandise due to the position of the elevator that is in the corner and the corridor used to display the merchandise. The position of the elevator in the corner is not visible from the basement stairs located in the middle of the building so it is difficult to find due to the visual perception in designing. Therefore, a designer needs to know the environmental perception of the building user to be a guide in designing. Then, the elevator is covered by merchandise because most sellers put merchandise over the corridor boundary so that visual access is 
blocked. This is because the corridor boundaries are dynamic and unclear so sellers use corridors to display merchandise. Therefore, the need to set static and clear corridor boundaries to make visitors oriented indoors.

\subsection{Searching for elevator while circling}

Previous discussions were discussed about searching an elevator when entering. It appears that the percentage of visitors who experience disorientation is more than those who experience orientation. This discussion will be discussed by visitors who are oriented and oriented when searching for elevators while circling around. Here's why and percentage of visitors in the table below.

\section{a. Orientation}

Visitors who experienced orientation when searching for elevator while circling were less than a third of visitors $(31.7 \%)$. The most reason visitors experience orientation is because of its position in the finished corner when the circumference is visible (20\%). The second most reason is because there are signage to the elevator $(5 \%)$. The third most reason is due to position memorization $(3.3 \%)$. Then the reason that has the smallest percentage is because MTC is small and the door looks large when roving $(1.7 \%)$.

The most reason visitors are oriented when searching for an elevator when circling because of its position in the corner so when walking around is seen to be related to the visual access to the elevator when circling. This condition occurs because when circling, visitors browse all parts of the building including the corner of the building so that the elevator is visible and find the elevator.

Table 6 . The reason and percentage of visitors who experience orientation and disorientation when searching for elevators while circling

\begin{tabular}{|c|c|c|c|}
\hline \multirow{2}{*}{$\begin{array}{l}\text { Orientation } \\
\text { Reason }\end{array}$} & \multirow[b]{2}{*}{$(\%)$} & \multicolumn{2}{|l|}{ Disorientation } \\
\hline & & Reason & $(\%)$ \\
\hline \multirow{2}{*}{$\begin{array}{l}\text { The position is } \\
\text { cornered, so when } \\
\text { the circumference } \\
\text { is visible }\end{array}$} & \multirow{2}{*}{20.0} & $\begin{array}{l}\text { Lots of corridors turns to } \\
\text { the elevator so hard to } \\
\text { find }\end{array}$ & 5.0 \\
\hline & & $\begin{array}{l}\text { Because not every corne } \\
\text { there is an elevator, so } \\
\text { confused which angle }\end{array}$ & 48.3 \\
\hline $\begin{array}{l}\text { There are signage } \\
\text { to elevator }\end{array}$ & 5.0 & $\begin{array}{l}\text { There are nosignage to } \\
\text { elevator }\end{array}$ & 1.7 \\
\hline $\begin{array}{l}\text { Memorize elevator } \\
\text { position }\end{array}$ & 3.3 & $\begin{array}{l}\text { Covered by sales desks } \\
\text { and retails }\end{array}$ & 6.7 \\
\hline \multirow[b]{2}{*}{ MTC size is small } & \multirow[b]{2}{*}{1.7} & $\begin{array}{l}\text { Not visible from the } \\
\text { middle of the building }\end{array}$ & 3.3 \\
\hline & & $\begin{array}{l}\text { The location is not } \\
\text { visible from the middle } \\
\text { of the building and there } \\
\text { are no signage }\end{array}$ & 1.7 \\
\hline $\begin{array}{l}\text { The door looks } \\
\text { large when circling }\end{array}$ & 1.7 & $\begin{array}{l}\text { There is no difference in } \\
\text { the size of the corridor } \\
\text { leading to the elevator } \\
\text { with the other corridor so } \\
\text { the corridor looks the } \\
\text { same }\end{array}$ & 1.7 \\
\hline Total & 31.7 & Total & 68.3 \\
\hline
\end{tabular}

The second most important reason visitors experience orientation is because there are signage to the elevator, showing the importance of a signage to orient the user. Visitors know and use signage because it has legibility properties. The third most reason is due to memorizing the position of the elevator, showing the ability to remember in the cognitive mapping that individuals have so as to imagine the routes that are passed to the elevator.

Then the reason with the smallest percentage of visitors experienced orientation because the size of MTC is small and the elevator door looks large when circling, related to the ability to remember individuals and design elements as markers. The ability to remember makes visitors can imagine the path being melted so feel that the size of MTC is small. Meanwhile, the elevator door that looks large when circling is associated with the design element as a marker. The large elevator door is a marker of the existence of the elevator. When visitors go around and through the elevator, the door can be seen by visitors so that visitors are oriented and know the existence of the elevator.

\section{b. Disorientation}

Visitors who experience disorientation when searching for elevators while circling in fewer than twothirds of visitors $(68.3 \%)$. This shows that most visitors experience disorientation or confusion searching for an elevator while circling. The reason most visitors experience disorientation is because the position of the elevator is in the corner so confused which angle because not all corners there are elevators $(48.3 \%)$. The second most reason is because the elevator is covered by sales desks and retails $(6.7 \%)$. The third most reason is because there are many corridor turns to the elevator so elevators are hard to find (5\%). The fourth most reason is because the elevator is not visible from the center of the building $(3.3 \%)$. Furthermore, the reason that has the smallest percentage is because there are no signage to the elevator, the location of the elevator is not visible from the center of the building and there is no signage, and there is no difference in the size of the corridor leading to the elevator with the other corridor so that the corridor looks the same $(1.7 \%)$.

The biggest reason is because not every corner there is an elevator so visitors are confused as to which corner the elevator is in, related to the inconsistencies of the design elements. MTC's box-shaped space plan doesn't have a strong image of each corner so visitors don't get markers to distinguish each angle. The second most reason is because elevators are covered by sales desks and retails make visitors disoriented, dealing with visual access difficulties. The corner elevator position and the store setting are quite congested making the elevator blocked by rows of shops. The third most reason is because there are so many corridor turns to the elevator that the elevator is difficult to find, showing the grid pattern in the MTC circulation makes visitors not know the path to the elevator when circling. Circulation patterns in MTC that form grid patterns form branching points making visitors confused to determine the right turn to get to the elevator. 
The fourth most reason for the elevator is not visible from the center of the building, describing visual access to the elevator is not visible in a strategic position in the building. The designer's visual perception puts the elevator in the corner so that the elevator can be exposed from the outside. As a result the elevator cannot be seen from the middle of the building. The reason with the smallest percentage is because there are no signage to the elevator, the location of the elevator is not visible from the middle of the building and there are no signage, and there is no difference in the size of the corridor leading to the elevator with the other corridor so that the corridor looks the same makes visitors experience disorientation. The absence of signage to the elevator shows the lack of legibility that signage has so visitors do not know and use existing signage. There is no difference in the size of the corridor leading to the elevator and the other corridor so the corridor looks the same, illustrating the lack of contrast between the corridor leading to the elevator and the other corridor. The lack of contrasting differences between corridors, resulting in corridors that have no legibility. As a result visitors have difficulty finding information that is used as a marker to remember the corridor leading to the elevator.

\section{Conclusions and Suggestions}

\subsection{Conclusions}

Based on the results of the research that has been discussed, the following conclusions can be drawn:

a. Factors related to the visitor's orientation experience are: spatial aspects, functional aspects, visual aspects, cognitive mapping, and behavior

b. Factors related to the visitor's disorientation experience are: spatial aspects, functional aspects, visual aspects, cognitive mapping, behavior, and internal individuals.

c. There are five factors in common with orientation and disorientation. However, there is one different factor that is the individual internal factor in the disorientation experience whereas in orientation is not found. This is because internal factors such as fatigue make it easy for a person to forget and not concentrate so that they experience disorientation.

\subsection{Suggestions}

In connection with the above conclusions, the following suggestions can be outlined:

a. Strengthens the legibility and imageability of spatial elements and functional elements as markers for easy reading or recognition and to evoke strong imagery in individual mental imagery.

b. In addition to the considerations in functional orientation that have been discussed in this study, there are still some other considerations to be used as research materials. Therefore, it is necessary to look for other considerations regarding functional orientation by some experts to see the relationship with spatial orientation.

c. This research was conducted before the pandemic, then further research is needed after the new normal.

\section{References}

[1] Narell, Mia Holland. For Disorientation. Tesis. Berkeley: University of California; 2016.

[2] Zahnd, Markus. Pendekatan dalam Perancangan Arsitektur. Yogyakarta: Kanisius; 2009.

[3] Rapoport, Amos. Human Aspects of Urban Form: Towards a Man Environment Approach to Urban Form and Design. Great Britain: Pergamon Press; 1977.

[4] Ahmed, Sara. Queer Phenomenology: Orientations, Objects, Others. United States of America: Duke University Press; 2006.

[5] Zube, Ervin H dan Moore, Gary T. Advanced in Environment, Behavior, and Design. Volume 2. New York: Plenum Press; 1989.

[6] Alan, Evision. Oxford Learner's Pocket Dictionary. New York: Oxford University Press; 1983.

[7] Departemen Pendidikan dan Kebudayaan R.I. Pedoman Umum Ejaan Bahasa Indonesia yang Disempurnakan. Jakarta: Balai Pustaka; 1975

[8] Schulz, Christian Norberg. Genius Loci: Towards a Phenomenology of Architecture. New York: Rizolli International Publication Inc.; 1979.

[9] Lynch, Kevin. A Theory of Good City Form. Cambridge: The MIT Press; 1981.

[10]Kling, Beate dan Kruger Torsten. Signage: Spatial Orientation Munich: Detail; 2013.

[11]Garling, Tommy dan Golledge, Reginald G. Environmental Perception and Cognition. Dalam: Zube, Ervin H dan Moore, Gary $\mathrm{T}$ (ed). Advances in Environment, Behavior, and Design. Volume 2. New York: Plenum Press; 1989.

[12] Ohta, Russel J. Spatial Orientation in The Elderly: The Current Status of Understanding. Dalam: Pick, Herbert L Jr dan Acredolo, Linda P (ed). Spatial Orientation: Theory, Research, and Application. New York: Plenum Press; 1983.

[13] Lynch, Kevin. The Image of the City. Cambridge: The MIT Press; 1960.

[14] Tanuwidjaja, Gunawan. Tinjauan Pustaka Wayfinding dan Orientation System, (Online), https://scribd.com/document/86547166/SS-Tinjauan-Pustaka-WayFinding. 2012.

[15] Gibson, David. The Wayfinding Handbook. New York: Princeton Architectural Press; 2009.

[16] Ven, Cornelis van de. Ruang dalam Arsitektur. Jakarta: PT. Gramedia Pustaka Mandiri. 1995.

[17] Leatherbarrow, David. Disorientation and Disclosure. Interstices Under Construction Symposium Unsettled Containers: Aspects of Interiority, October 8-10 ${ }^{\text {th }}$, 2010. University of Auckland, Auckland, New Zealand; 2010. pp 93-104.

[18] Coleman, Peter. Shopping Environments: Evolution, Planning, and Design. Italy: Architectural Press; 2006.

[19] Golledge, Reginald G., Wayfinding Behavior, Cognitive Mapping, and Other Spatial Processes. London: The Johns Hopkins University Press; 1999.

[20]Hunter, Rebecca H., Anderson, Lynda A., Belza, Basia L. Community Wayfinding: Pathways to Understanding. Switzerland: Springer International Publishing; 2016.

[21] Iskandar, Zulriska. Psikologi Lingkungan. Bandung: PT. Refika Aditama; 2016.

[22] Harisah, Afifah dan Masiming, Zulfitria. Persepsi Manusia terhadap Tanda, Simbol, dan Spasial. Jurnal Smartek. 2008; 6(1): $29-43$

[23] Haryadi dan Setiawan, B. Arsitektur Lingkungan dan Perilaku. Yogyakarta: Proyek Pengembangan Pusat Studi Lingkungan Direktorat Jendral Pendidikan Tinggi Departemen Pendidikan dan Kebudayaan Republik Indonesia; 1995.

[24] Indrawan, Rully dan Yaniawati, Poppy. Metodologi Penelitian: Kuantitatif, Kualitatif, dan Campuran Untuk Manajemen, Pembangunan, dan Pendidikan. Bandung: Refika Aditama; 2014.

[25]Dunn dan Rankin. Scaling Methods. New Jersey: Lawrence Elbaum; 2004.

[26] Azwar, Saifuddin. Reliabilitas dan Validitas. Yogyakarta: Pustaka Pelajar; 2006. 